\title{
A Decision-making Method for Active Remanufacturing Time Based on Environmental and Economic Indicators
}

\author{
https://doi.org/10.3991/ijoe.v12i12.6455 \\ Qin Xiang, Hua Zhang, Zhigang Jiang, Shuo Zhu, Wei Yan \\ Wuhan University of Science \& Technology, Wuhan, China
}

\begin{abstract}
Optimal status and performance of the used parts can often make the difference between successful and unsuccessful remanufacturing for construction machinery. However, a used parts is remanufactured at an unreasonable time, there is a greater degree of resource waste and diseconomy. In this paper, a new method for determining the optimum active remanufacturing time is proposed, which considers both environmental and economic indicators. As an example, the life cycle assessment method was adopted for assessing the environmental impact of an oil cylinder over its entire service life, and an average annual cost model was established. Considering both the environmental index and the cost index, an optimization process was performed and the optimum active remanufacturing time for the oil cylinder was determined to be after 6.58 years of operation.
\end{abstract}

Index Terms-Active remanufacturing time, construction machinery, Environmental indicator, Economic indicator, Life cycle assessment

\section{INTRODUCTION}

With the increasing awareness of environmental protection worldwide, the green trend of conserving the Earth's resources and protecting the environment is overwhelming. The conversation of resources is being considered from many aspects on product development and use, such as redesign, reuse, recycle, and remanufacture of products and components. Remanufacturing is a powerful product recovery option which generates products as good as new ones from old discarded ones ${ }^{[1]}$. This technique can also help to reduce the environmental impact of the product in its final disposal ${ }^{[2]}$.

The used products remanufacturing have been investigated in the last decades, especially in the field of construction machinery, remanufacturing has huge potential. Construction machinery is an important remanufacturing target due to its large volume and wide covering, complicated manufacturing process, and huge material consumption ${ }^{[3]}$. However, for remanufacturing, the main problem is the collection of used key parts with good quality at the right time. Due to the uncertainty of the service life and performance of used parts, it is not easy to estimate when the used parts is recycled. This above factor has directly affects the following remanufacturing strategy. It is known that large construction machinery such as concrete pump truck, the oil cylinder as the key part is remanufactured when it was completely abandoned, but not all of the retired parts can be remanufactured. Currently it is com- mon to remanufacture 'over-used' products, which leads to higher costs and more serious environmental pollution than the original manufacture. Sometimes such products cannot be remanufactured at all because of difficult technique. On the other hand, a 'premature remanufacturing' will lead to a huge amount of waste ${ }^{[4]}$. Therefore, it is necessary to start the remanufacturing process at a reasonable time before the end of the product's service life, which is referred to as "active remanufacturing". Active remanufacturing is based on remanufacturing a product before it is scrapped, which allows to reduce the energy consumption during remanufacturing and to improve the overall efficiency of the remanufacturing process ${ }^{[5]}$.

Many studies on active remanufacturing have been done, and developed lots kinds of methods to solve the problem. Liu et al. claimed that remanufacturing blanks are waste products that have been completely scrapped, have lost their functionality, and are of variable quality, and that these blanks can only be remanufactured passively, individually, personalized ${ }^{[6]}$, which is a very complex and inefficient method. The most effective way for promoting the development of remanufacturing is to already consider remanufacturing during the initial product design phase ${ }^{[7-9]}$. Therefore, Zhang et al. developed an assessing model for remanufacturability based on the assemblability, consisting of two key modules, the technological module and the economical module ${ }^{[10]}$, which provides a framework for research on active remanufacturing.

However, the main problem that needs to be solved for a successful implementation of active remanufacturing is determination of the optimal time for remanufacturing. In this paper, a method for determining the optimal active remanufacturing timing with full consideration of both environmental and economic indicators is proposed.

\section{THE CONCEPT OF ACTIVE REMANUFACTURING AND OPTIMAL TIMING OF THE REMANUFACTURING PROCESS}

\section{A. The concept of active remanufacturing}

Throughout a product's service life, there are three obvious failure periods: early failure, accidental failure and wear-out-failure, which can be illustrated by a U-shaped curve. Modeling of active remanufacturing is usually based on the wear behavior of the components, which emphasizes the need to eliminate performance degradation during the embryonic stage. The end of the second phase of the regular wear curve is defined as the time limit for 
"preventive remanufacturing", and the remanufacturing time is always set up based on the practical product's service life. Therefore, a typical time window for "active remanufacturing" can be set up at the end of the second part of the U-shaped curve, as illustrated in Figure 1.

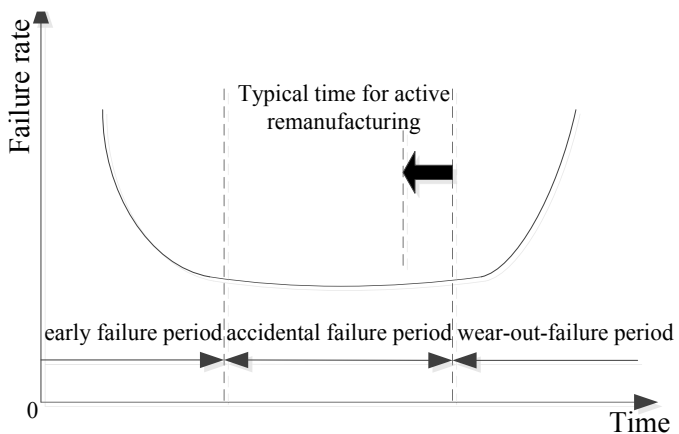

Figure 1. U-shaped curve illustrating the three failure periods a product's service life

Active remanufacturing involves a series of engineering activities, which are conducted to actively implement the remanufacturing of products at some point during their service life to guarantee the functionality and performance of the original product design incorporating the concept of a high quality, high efficiency, energy and materials saving, environmental protection and product life extension as guiding principles. During the life cycle of each product, there is an optimal point for remanufacturing. Active remanufacturing aims to start a new cycle at this point in time to minimize the overall environmental impact and the costs over the whole service period, as shown in Figure 2.

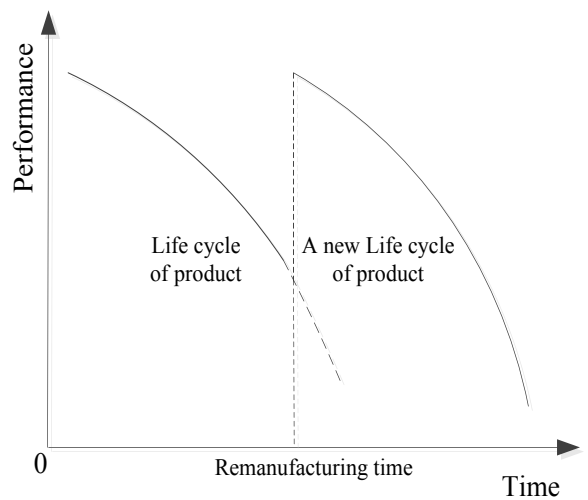

Figure 2. Performance deterioration of components before and after remanufacturing

\section{B. Optimal timing of the remanufacturing process}

Active remanufacturing considers the relationship between the environmental impact and the manufacturing costs during a product life cycle. In this context, the point of optimal timing for remanufacturing is defined as the time when the product's performance starts to degenerate. Two performance indexes will change regularity with increasing usage time over the product's lifecycle. Using the average usage time of these two indexes as a function, and taking the usage time as an independent variable, then the change rule can be expressed qualitatively. In this study, we adopted a Life Cycle Assessment (LCA) method is adopted to identify the optimal timing of the remanufacturing process.

1) Definition of the average environmental impact index function
The environmental impact evaluation value $(E I)$ can be calculated for each of the four product life cycle stages: the original manufacturing process, first-cycle usage, the remanufacturing process, and second-cycle usage. The total $E I$ can be expressed as:

$$
\sum E I_{k}=E I_{1}+E I_{2}+E I_{3}+E I_{4}
$$

where $E I_{1}$ is the environmental impact of the original manufacturing process, $E I_{2}$ is the environmental impact during the first-cycle usage, $E I_{3}$ is the environmental impact of the remanufacturing process, and $E I_{4}$ is the environmental impact during the second-cycle usage.

As an example, assume that an oil cylinder is remanufactured after it has been used for $n_{1}$ years during the first-cycle usage stage and can be used for another $n_{2}$ years in the second-cycle usage stage. Then, the average environmental impact $F(n)_{i}$ can be expressed as:

$$
F(n)_{i}=\frac{\sum E I_{k}}{n_{1}+n_{2}}=\frac{E I_{1}+E I_{2}+E I_{3}+E I_{4}}{n_{1}+n_{2}}
$$

In this study, the EI values were obtained through the LCA method, and the individual steps of the assessment process are as follows ${ }^{[11]}$ :

The firstly, selection and definition of the type of influence: identification of the relevant environmental impact categories, e.g., the global warming potential, acidification potential, eutrophication potential.

The secondly, classification of the results of the inventory analysis to the corresponding environmental impact type. For instance, the $\mathrm{CO}_{2}$ emissions were classified as contributing to global warming.

The thirdly, characterization: Quantification of the results of the environmental impact analysis for each of the inventory items by using scientific equivalence factors. For example, the Global Warming Potential was adopted to quantify the environmental impact of $\mathrm{CO}_{2}$ and $\mathrm{CH}_{4}$ emissions.

The forth, standardization to better understand the relative impact of each parameter and weighting to ensure that the level of importance of each type of environmental impact is considered.

Eight impact indicators were considered in this study Main dependent variables for each of the impact indicators are shown in TABLE I

TABLE I.

THE IMPACT INDICATORS AND THEIR MAIN DEPENDENT FACTORS UNITS

\begin{tabular}{|c|c|}
\hline Impact Indicators & Main Dependent Factors \\
\hline $\begin{array}{l}\text { Primary Energy Demand } \\
\text { (PED), }\end{array}$ & $\begin{array}{l}\text { coal, oil, natural gas and other energy } \\
\text { consumption }\end{array}$ \\
\hline $\begin{array}{l}\text { Global Warming Potential } \\
\text { (GWP) }\end{array}$ & $\begin{array}{c}\text { greenhouse gas emissions, e.g., } \mathrm{CO}_{2} \text {, } \\
\mathrm{CH} 4, \mathrm{NOx}, \mathrm{CO}\end{array}$ \\
\hline Acidification Potential (AP) & $\mathrm{SO}_{2}, \mathrm{NOx}, \mathrm{NH} 3$ emissions \\
\hline $\begin{array}{l}\text { the Eutrophication Potential } \\
\qquad(\mathrm{EP})\end{array}$ & COD, NOx and NH3 emissions \\
\hline Respiratory Inorganics (RI) & $\begin{array}{l}\text { particulate matter emissions into the } \\
\text { atmosphere (PM2.5) }\end{array}$ \\
\hline Solid Waste produced & industrial waste \\
\hline Water Consumption & $\begin{array}{l}\text { fresh water consumption during the } \\
\text { industrial manufacturing process; }\end{array}$ \\
\hline $\begin{array}{l}\text { Chemical Oxygen Demand } \\
\text { (COD) }\end{array}$ & COD \\
\hline
\end{tabular}
FOR MAGNETIC PROPERTIES 
Then, the LCA method was employed to calculate the final environmental impact indicator according to the following equation:

$$
E I_{k}=\sum_{j=1}^{n} V_{j} \frac{\sum_{i=1}^{m} Q_{i} E P_{i}}{R_{j}}
$$

In Eq. (3), $E I_{k}$ represents the environmental impact of the ${ }^{\text {th }}$ stage, with $k=1,2,3,4 ; V_{j}$ is the weight factor of the $j^{\text {th }}$ indicator; $Q_{i}$ is the value of the $i^{\text {th }}$ substance in the lifecycle inventory; $E P_{i}$ is the characterization factor of the $i^{t h}$ substance with respect to the $j^{\text {th }}$ indicator; and $R_{j}$ is the reference value of the $j^{\text {th }}$ indicator.

Subsequently, for each value of $n_{1}$, the $E I_{k}$ value for each of the four stages can be calculated with through Eq. (3), and the value of $F(n)_{i}$ can be obtained through solving Eq. (2). Finally, the Average Environmental Impact Index $F(n)$ can be obtained by numerical curve fitting.

\section{2) Definition of the average cost index function}

The overall life cycle cost is the sum of the product research and design, manufacturing, usage and recycling costs for each stage of the lifecycle. A breakdown of the cost structure is given in TABLE II.

TABLE II.

THE OVERALL LIFECYCLE COST COMPOSITION OF A PRODUCT

\begin{tabular}{ccc}
\hline $\begin{array}{c}\text { Lifecycle cost } \\
\text { type }\end{array}$ & Cost type & cost composition \\
\hline $\begin{array}{c}\text { Production costs } \\
(C)\end{array}$ & Design costs & $\begin{array}{c}\text { Market research, feasibility studies, } \\
\text { tests, patent fees, development and } \\
\text { planning, etc. }\end{array}$ \\
& $\begin{array}{c}\text { Manufacturing } \\
\text { costs }\end{array}$ & $\begin{array}{c}\text { Cost of raw materials, processing, } \\
\text { assembling and debugging, packag- } \\
\text { ing, transportation, inventory man- } \\
\text { agement, etc. }\end{array}$ \\
$\begin{array}{c}\text { Usage and } \\
\text { maintenance } \\
\text { costs }\left(C_{u} \text { and }\right. \\
\left.C_{r u}\right)\end{array}$ & Operation costs & $\begin{array}{c}\text { Labor costs, energy cost, material } \\
\text { costs, additional, etc. }\end{array}$ \\
Maintenance & costs & $\begin{array}{c}\text { Material costs, labour costs, downtime } \\
\text { costs. upgrades and reconstruction, } \\
\text { etc. }\end{array}$
\end{tabular}

Remanufactur- Recycling and Collecting and logistics, dismantling, ing costs remanufacturing cleaning, product analysis and repro$\left(C_{r m}\right) \quad$ costs $\quad$ cessing costs, etc.

Then, the overall lifecycle cost of a product $\left(C_{t}\right)$ can be expressed as follows:

$$
C_{t}=C+C_{u}+C_{r m}+C_{r u}
$$

where $C$ denotes the development and production costs, which is expressed by Eq. (5); $C_{u}$ represents the operation and maintenance costs as given in Eq. (6), and $C_{r}$ denotes the operation costs after remanufacturing.

$$
\begin{aligned}
& C=\left(C_{m}+C_{w}\right)(1+r) \\
& C_{u}=\sum C_{n} r_{p}
\end{aligned}
$$

In Eq. (5), $C_{m}$ represents the material costs per product unit, $C_{w}$ represents the wages of the workers per product unit, $r$ represents the ratio of the management cost to the sum of the material costs and wages.

In Eq. (6), $C_{n}$ denotes the operation and maintenance costs during the nth year, given by Eq. (7), and $r_{p}$ is the discount factor, which can be calculated by Eq. (8).

$$
C_{n}=C_{1}(1+g)^{n-1}
$$

$$
r_{\mathrm{p}}=\frac{1}{(1+i)^{n}}
$$

In Eq. (7), $C_{1}$ represents the maintenance costs for the first year, and $\mathrm{g}$ is the degree of deterioration, which is assumed to be $3 \% .^{[12]}$

In Eq. (8), $i$ is the annualized rate, which is assumed to be $4.3 \%$, which is the current annualized rate of Bank of China.

The average cost index function $C(n)$ can be obtained by combining Eq. (4)-(8).

$$
C(n)=\left(C+C_{\mathrm{rm}}+\sum C_{n} r_{\mathrm{p}}\right) r_{\mathrm{v}}
$$

where $r_{v}$ represents the annual conversion coefficient which can be calculated as follows:

$$
r_{\mathrm{v}}=\frac{i(1+i)^{n}}{(1+i)^{n}-1}
$$

$C(n)$ can be obtained by solving Eq. (9), and a curve can be fitted to the graph of $C(n)$. Finally, combining the function $F(n)$ and the function $C(n)$, the optimal timing for remanufacturing can be calculated.

\section{TIME DECISION For THE ACTIVE REMANUFACTURING OF AN OIL CYLINDER}

An oil cylinder is a critical component linked to the boom of a concrete pump truck, providing the power for the boom's rotation. The service life of the oil cylinder determines the service life of the concrete pump truck. At present, the remanufacturing of oil cylinders is mostly conducted after losing the function, which increases remanufacturing costs and results in a waste of resources. Therefore, applying active remanufacturing to oil cylinders is very likely to generate significant economic and environmental benefits.

\section{A. Environmental impact index function for an oil cylinder}

1) Environmental impact of the original manufacturing process $\left(E_{l}\right)$

Stage one covers the production of the raw materials, manufacturing of the components as well as transportation. The oil cylinder consists of an end cover, a piston, a piston rod, a cylinder and other components. The main raw materials are steel and cast iron, and the quantity of raw materials required for each component is given in TABLE III.

TABLE III.

RAW MATERIALS AND ENERGY CONSUMPTION FOR THE MANUFACTURING OF AN OIL CYLINDER

\begin{tabular}{cccc}
\hline \hline Component & $\begin{array}{c}\text { Raw mate- } \\
\text { rial }\end{array}$ & Quantity $(\mathrm{kg})$ & $\begin{array}{c}\text { Energy consumption } \\
(\mathrm{kWh})\end{array}$ \\
\hline End cover & Cast iron & 1.96 & 2.1 \\
Piston & Cast iron & 3.62 & 11.9 \\
Piston rod & Steel & 88.74 & 250.9 \\
Cylinder & Cast iron & 54.26 & 97.3 \\
Other components & $/$ & 15.16 & 9.8 \\
Aggregate & $/$ & 163.74 & 372 \\
\hline \hline
\end{tabular}

The fabrication of the raw materials requires the use of coal, crude oil, and natural gas. Greenhouse gases, such as $\mathrm{CO}, \mathrm{CO}_{2}, \mathrm{SO}_{2}$, are released by burning these fuels. The fabrication of $1 \mathrm{~kg}$ of raw material is associated with a 
certain COD, release of ammonia and nitrogen and a certain amount of solid wastes. The production of the components also includes the transportation of the raw materials and electric energy for production processes. The inventory data for the extraction and production of $1 \mathrm{~kg}$ of raw material is taken from the Chinese Life Cycle Database (CLCD) and the detailed values are listed in TABLE IV.

Referring to TABLE II, material a total of $59.84 \mathrm{~kg}$ of cast iron and $88.74 \mathrm{~kg}$ of steel were required for the fabrication of the oil cylinder. It was assumed that the total distance for the transportation of the raw materials was assumed to be $160 \mathrm{~km}$. A gasoline-fueled truck with a loading capacity of 10 tons was taken for the transport of the raw materials to the job-shop. Life cycle inventory data for the original manufacturing of the oil cylinder was calculated based on TABLE III. Subsequently, the environmental impact was evaluated by characterizing, standardizing and weighting the contributions of the eight different types of environmental impact. The characterization factor and the weighting factor were also taken from the CLCD. The life cycle inventory data for the original manufacturing process of the oil cylinder is listed in TABLE V.

Finally, the environmental impact of the original manufacturing process of the oil cylinder was calculated to be equal to 329 based on Eq. (3).

\section{2) Environmental impact of the remanufacturing} process (E3)

The average life span of an oil cylinder is at least 10 years, according to industrial survey results. For this anal-

TABLE IV.

INVENTORY DATA FOR THE EXTRACTION AND PRODUCTION OF L KG OF RAW MATERIAL

\begin{tabular}{|c|c|c|c|c|c|}
\hline Impact type & $\begin{array}{c}\text { Invento- } \\
\text { ry } \\
\text { sub- } \\
\text { stance }\end{array}$ & $\begin{array}{l}\text { Produc- } \\
\text { tion of } \\
\text { cast iron } \\
(\mathrm{kg})\end{array}$ & $\begin{array}{l}\text { Produc- } \\
\text { tion of } \\
\text { steel }(\mathrm{kg})\end{array}$ & $\begin{array}{c}\text { Electric } \\
\text { energy } \\
(\mathrm{kg})\end{array}$ & $\begin{array}{c}\text { Transporta- } \\
\text { tion }(\mathrm{kg})\end{array}$ \\
\hline \multirow{3}{*}{ PED } & Coal & $1.25 \mathrm{E} 03$ & $1.44 \mathrm{E} 00$ & $\begin{array}{c}5.86 \mathrm{E}-0 \\
1\end{array}$ & $3.46 \mathrm{E}-03$ \\
\hline & Crude oil & $4.46 \mathrm{E} 01$ & 4.67E-02 & $\begin{array}{c}3.05 \mathrm{E}-0 \\
3\end{array}$ & 4.12E-02 \\
\hline & $\begin{array}{c}\text { Natural } \\
\text { gas }\end{array}$ & $2.49 \mathrm{E}-01$ & 2.89E-03 & $\begin{array}{c}1.05 \mathrm{E}-0 \\
4\end{array}$ & 8.99E-04 \\
\hline \multirow[t]{3}{*}{$\begin{array}{l}\text { Water } \\
\text { Consump- } \\
\text { tion }\end{array}$} & $\begin{array}{l}\text { Fresh } \\
\text { water }\end{array}$ & $1.11 \mathrm{E} 04$ & $1.57 \mathrm{E} 01$ & $3.17 \mathrm{E} 00$ & $1.2 \mathrm{E}-01$ \\
\hline & $\mathrm{CO}_{2}$ & $1.27 \mathrm{E} 03$ & $1.49 \mathrm{E} 00$ & $\begin{array}{c}1.53 \mathrm{E}-0 \\
2\end{array}$ & $1.07 \mathrm{E}-01$ \\
\hline & $\mathrm{NH}_{4}$ & $5.58 \mathrm{E} 00$ & $6.46 \mathrm{E}-03$ & $\begin{array}{c}2.62 \mathrm{E}-0 \\
3\end{array}$ & $5.8 \mathrm{E}-04$ \\
\hline \multirow{3}{*}{ GWP } & $\mathrm{NO}_{\mathrm{x}}$ & $2.58 \mathrm{E} 00$ & $3.21 \mathrm{E}-03$ & $\begin{array}{c}2.59 \mathrm{E}-0 \\
3\end{array}$ & $1.96 \mathrm{E}-03$ \\
\hline & $\mathrm{CO}$ & 2.59E01 & $3 \mathrm{E}-02$ & $\begin{array}{c}1.72 \mathrm{E}-0 \\
4\end{array}$ & $1.73 \mathrm{E}-02$ \\
\hline & $\mathrm{SO}_{2}$ & $2.82 \mathrm{E} 00$ & $3.6 \mathrm{E}-03$ & $\begin{array}{c}3.16 \mathrm{E}-0 \\
3\end{array}$ & $1.29 \mathrm{E}-04$ \\
\hline AP & $\mathrm{NO}_{\mathrm{x}}$ & $2.58 \mathrm{E} 00$ & $3.21 \mathrm{E}-03$ & $\begin{array}{c}2.59 \mathrm{E}-0 \\
3\end{array}$ & $1.96 \mathrm{E}-03$ \\
\hline & $\mathrm{NH}_{3}$ & $1.46 \mathrm{E}-01$ & $1.53 \mathrm{E}-04$ & 3.7E-06 & $2.27 \mathrm{E}-07$ \\
\hline RI & PM2.5 & 2.27E00 & $3.18 \mathrm{E}-03$ & $\begin{array}{c}9.59 \mathrm{E}-0 \\
4\end{array}$ & $5.73 \mathrm{E}-06$ \\
\hline \multirow{3}{*}{ EP } & $\mathrm{NO}_{\mathrm{x}}$ & $2.58 \mathrm{E} 00$ & $3.21 \mathrm{E}-03$ & $\begin{array}{c}2.59 \mathrm{E}-0 \\
3\end{array}$ & $1.96 \mathrm{E}-03$ \\
\hline & $\mathrm{NH}_{3}$ & $1.46 \mathrm{E}-01$ & $1.53 \mathrm{E}-04$ & 3.7E-06 & $2.27 \mathrm{E}-07$ \\
\hline & COD & $3.34 \mathrm{E}-01$ & $3.72 \mathrm{E}-04$ & $1.5 \mathrm{E}-05$ & $7.74 \mathrm{E}-05$ \\
\hline Solid Waste & $\begin{array}{l}\text { Industri- } \\
\text { al waste }\end{array}$ & 2.09E02 & $2.32 \mathrm{E}-01$ & $\begin{array}{c}1.22 \mathrm{E}-0 \\
2\end{array}$ & $9.26 \mathrm{E}-05$ \\
\hline COD & COD & 3.34E-01 & 3.72E-04 & $1.5 \mathrm{E}-05$ & 7.74E-05 \\
\hline
\end{tabular}

TABLE V.

LIFE CYCLE INVENTORY DATA FOR THE ORIGINAL MANUFACTURING OF AN OIL CYLINDER

\begin{tabular}{|c|c|c|c|c|c|c|}
\hline $\begin{array}{l}\text { Impact } \\
\text { type }\end{array}$ & $\begin{array}{l}\text { Inventory } \\
\text { substance }\end{array}$ & $\begin{array}{l}\text { Inventory } \\
\text { data (kg) }\end{array}$ & $\begin{array}{c}\text { Characteriza- } \\
\text { tion factor ( } g \\
\text { ) }\end{array}$ & $\begin{array}{c}\text { Characteriza- } \\
\text { tion results } \\
(\mathrm{kg})\end{array}$ & $\begin{array}{l}\text { Standardiza- } \\
\text { tion value }^{[\mathrm{a}]}\end{array}$ & $\begin{array}{c}\text { Weightin } \\
\mathrm{g} \text { factor }\end{array}$ \\
\hline \multirow{3}{*}{ PED } & Coal & $7.52 \mathrm{E}+04$ & 0.714 & \multirow{3}{*}{$5.76 \mathrm{E}+04$} & \multirow{3}{*}{2226} & \multirow{3}{*}{0.203} \\
\hline & Crude oil & $2.74 \mathrm{E}+03$ & 1.429 & & & \\
\hline & $\begin{array}{c}\text { Natural } \\
\text { gas }\end{array}$ & $1.66 \mathrm{E}+01$ & 1.33 & & & \\
\hline \multirow{2}{*}{$\begin{array}{c}\text { Water } \\
\text { Con- } \\
\text { sumption }\end{array}$} & $\begin{array}{l}\text { Fresh } \\
\text { water }\end{array}$ & $6.67 \mathrm{E}+05$ & 1 & $6.67 \mathrm{E}+05$ & 107000 & 0.166 \\
\hline & $\mathrm{CO}_{2}$ & $7.63 \mathrm{E}+04$ & 1 & \multirow{4}{*}{$1.32 \mathrm{E}+05$} & \multirow{4}{*}{12291} & \multirow{4}{*}{0.714} \\
\hline \multirow[t]{3}{*}{ GWP } & $\mathrm{NH}_{4}$ & $3.36 \mathrm{E}+02$ & 25 & & & \\
\hline & $\begin{array}{l}\mathrm{NO}_{\mathrm{x}} \\
\mathrm{CO}\end{array}$ & $\begin{array}{l}1.59 \mathrm{E}+02 \\
1.58 \mathrm{E}+03\end{array}$ & $\begin{array}{c}298 \\
2\end{array}$ & & & \\
\hline & $\mathrm{SO}_{2}$ & $1.70 \mathrm{E}+02$ & 1 & & & \\
\hline \multirow[t]{2}{*}{ AP } & $\mathrm{NO}_{\mathrm{x}}$ & $1.59 \mathrm{E}+02$ & 0.7 & \multirow[t]{2}{*}{$2.98 \mathrm{E}+02$} & \multirow[t]{2}{*}{31} & \multirow[t]{2}{*}{0.103} \\
\hline & $\mathrm{NH}_{3}$ & $8.75 \mathrm{E}+00$ & 1.88 & & & \\
\hline RI & PM2.5 & $1.36 \mathrm{E}+02$ & 1 & $1.36 \mathrm{E}+02$ & 11 & 0.078 \\
\hline \multirow{3}{*}{ EP } & $\mathrm{NO}_{\mathrm{x}}$ & $1.59 \mathrm{E}+02$ & 0.13 & \multirow{3}{*}{$2.41 \mathrm{E}+01$} & \multirow{3}{*}{3} & \multirow{3}{*}{0.112} \\
\hline & $\mathrm{NH}_{3}$ & $8.75 \mathrm{E}+00$ & 0.35 & & & \\
\hline & COD & $2.01 \mathrm{E}+01$ & 0.022 & & & \\
\hline $\begin{array}{l}\text { Solid } \\
\text { Waste }\end{array}$ & $\begin{array}{l}\text { Industri- } \\
\text { al waste }\end{array}$ & $1.25 \mathrm{E}+04$ & 1 & $1.25 \mathrm{E}+04$ & 3.4 & 0.085 \\
\hline COD & COD & $2.01 \mathrm{E}+01$ & 1 & $2.01 \mathrm{E}+01$ & 9.2 & 0.079 \\
\hline
\end{tabular}

Note: [a] equivalent value according to national standardization (2009).

ysis, five different remanufacturing points were selected,i.e., assuming that the oil cylinder is remanufactured at the 2nd, 4th, 6th, 8th and 10th year, respectively. The remanufacturing processes and materials consumption during the remanufacturing process are illustrated in Figure 3 . In addition, both materials and energy consumption for the five different remanufacturing time points are shown in TABLE VI. The gasoline consumption during the recovery stage is constant and independent of the remanufacturing point. During the cleaning process, the consumption of diesel and kerosene linearly changes linearly as the remanufacturing time is gradually shifted further into the future. The values listed for the consumption of the electrode material and chromium during remanufacturing processes, as well as the energy consumption , are based on industrial research data.

The energy consumption and gas emission data during remanufacturing processes was again taken from the CLCD database. The method for calculating $E_{3}$ is the same for calculating $E_{1}$. The results obtained for $E_{3}$ are compared in TABLE VII for the different remanufacturing time points.

3) Environmental impact during the first-cycle and second-cycle usage ( $E_{2}$ and $\left.E_{4}\right)$

Hydraulic oil is consumed during the operation of the oil cylinder, so the energy consumption during usage mainly stems from the production of hydraulic oil. As the average service life of the oil cylinder is 10 years. If the

TABLE VI.

ENERGY AND MATERIAL CONSUMPTION DURING REMANUFACTURING FOR THE DIFFERENT REMANUFACTURING POINTS

\begin{tabular}{cccccc}
\hline \hline $\begin{array}{c}\text { Remanufacturing } \\
\text { time(year) }\end{array}$ & $\begin{array}{c}\text { Petrol Kerosene } \\
(\mathrm{kg})\end{array}$ & $\begin{array}{c}\text { Electricity } \\
(\mathrm{kg})\end{array}$ & $\begin{array}{c}\text { Low carbon } \\
(\mathrm{kWh})\end{array}$ & $\begin{array}{c}\text { Steel }(\mathrm{kg}) \\
(\mathrm{kg})\end{array}$ \\
\hline 2 & 43.5 & 0.64 & 14.5 & 0 & 0.002 \\
4 & 43.5 & 0.768 & 18 & 0.0064 & 0.004 \\
6 & 43.5 & 1.36 & 24.2 & 0.0096 & 0.006 \\
8 & 43.5 & 2.08 & 30.8 & 0.0256 & 0.0075 \\
10 & 43.5 & 3.2 & 44.5 & 0.032 & 0.0115 \\
\hline \hline
\end{tabular}


PAPER

A Decision-MAKing Method for ACtive Remanufacturing TIME BASED on ENVIRONMENTAL AND ECONOMIC INDICATORS

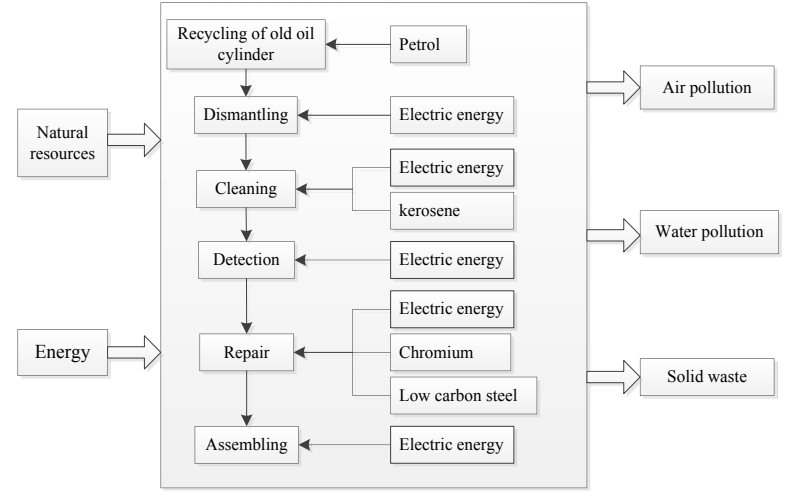

Figure 3. Remanufacturing of the oil cylinder and materials consumption

TABLE VII

COMPARISON OF THE E3 VALUES OBTAINED FOR THE DIFFERENT REMANUFACTURING POINTS

\begin{tabular}{cc}
\hline \hline Remanufacturing time(year) & $E_{3}$ \\
\hline 2 & 27.5 \\
4 & 42.9 \\
6 & 78.5 \\
8 & 102.8 \\
10 & 134.2 \\
\hline
\end{tabular}

hydraulic oil in the oil cylinder will be replaced 24 times during its life if it is replaced every five months. If we assume that $100 \mathrm{~L}$ of oil are replaced each time, and the density of hydraulic oil is $0.872 \mathrm{~kg} / \mathrm{L}$, then the environmental impact during the first-cycle usage can be calculated with the same method for calculating $E_{l}$.

During the second life cycle, it is assumed that the remanufactured oil cylinder shows the same performance as the original one. The remanufactured oil cylinder can again be operated for ten years. Therefore, the environmental impact during the second-cycle can be also calculated as the first life cycle. The results obtained for E2 and E4 are shown in TABLE VIII.

Using the data in TABLE IX, the Average Environmental Impact Index Curve (AEIIC) for the different remanufacturing points was plotted in MATLAB. Let $n$ characterize the service time of oil cylinder, which is from 0 to 10 . Then the following equation was obtained through fitting a conic curve to the AEIIC:

$$
F(n)=0.215 n^{2}-5.479 n+158.16
$$

4) Average environmental impact index function

The $E_{i}$ values obtained for the different remanufacturing points are compared in TABLE IX.

Then, the average environmental impact index $F_{i}$ for the different remanufacturing points can be calculated according to Eq. (2), and the results are shown in TABLE $\mathrm{X}$.

\section{B. Average cost index function for the oil cylinder}

As mentioned in Section II, the cost of the oil cylinder over its full life cycle can be divided into producing costs, operation costs in the first life cycle, remanufacturing costs and operation costs in the second life cycle. To simplify the calculation, the production cost of the oil cylinder was regarded as the cost of purchase, in this case 11000 yuan. The operation cost of the oil cylinder is mainly related to hydraulic oil consumption. In Section 2), the amount of hydraulic oil consumed every 5 months was assumed to be $50 \mathrm{~L}$, and the unit price of hydraulic oil is $15.4 y u a n / L$. Assumed that based on a deterioration of $3 \%$, the operation cost in the second life cycle is fixed to 21188.25 yuan. By selecting five remanufacturing sample points, in different remanufacturing time points, the operation costs in the first life cycle were determined.

The costs of the production and operation of the oil cylinder for the five different remanufacturing time points are listed in TABLE XI. The remanufacturing costs data were determined through a survey from remanufacturing companies.

Then, the average cost index $C_{i}$ can be calculated using Eq. (9) for each of the five different remanufacturing points, and the results are shown in TABLE XII.

Using the data presented in TABLE $X$, the Average Cost Index Curve was plotted in MATLAB. Then, the fol-

TABLE VIII.

COMPARISON OF THE VALUES OBTAINED FOR E2 AND E4 FOR THE FIVE DIFFERENT REMANUFACTURING POINTS

\begin{tabular}{ccc}
\hline \hline Remanufacturing time(year) & $E_{2}$ & $E_{4}$ \\
\hline 2 & 406.7 & 1016.3 \\
4 & 559.1 & 1016.3 \\
6 & 711.5 & 1016.3 \\
8 & 863.9 & 1016.3 \\
10 & 1016.3 & 1016.3 \\
\hline \hline
\end{tabular}

TABLE IX.

COMPARISON OF THE ENVIRONMENTAL IMPACT INDICATOR VALUES OBTAINED FOR THE DIFFERENT REMANUFACTURING POINTS

\begin{tabular}{ccccc}
\hline \hline Remanufacturing time (year) & $E_{1}$ & $E_{2}$ & $E_{3}$ & $E_{4}$ \\
\hline 2 & 329 & 406.7 & 27.5 & 1016.3 \\
4 & 329 & 559.1 & 42.9 & 1016.3 \\
6 & 329 & 711.5 & 78.5 & 1016.3 \\
8 & 329 & 863.9 & 102.8 & 1016.3 \\
10 & 329 & 1016.3 & 134.2 & 1016.3 \\
\hline \hline
\end{tabular}

TABLE $X$.

AVERAGE ENVIRONMENTAL IMPACT INDEX FOR THE DIFFERENT REMANUFACTURING POINTS

\begin{tabular}{cccccc}
\hline \hline $\begin{array}{c}\text { Remanufacturing } \\
\text { time(year) } n\end{array}$ & 2 & 4 & 6 & 8 & 10 \\
\hline $\begin{array}{c}\text { the average environ- } \\
\text { mental impact index } F_{i}\end{array}$ & 148.29 & 139.09 & 133.46 & 128.11 & 124.79 \\
\hline \hline
\end{tabular}

TABLE XI.

COMPARISON OF THE OVERALL COST OF THE OIL CYLINDER FOR THE FIVE DIFFERENT REMANUFACTURING TIME POINTS

\begin{tabular}{ccccc}
\hline \hline $\begin{array}{c}\text { Remanufactur- } \\
\text { ing time(year) }\end{array}$ & $\begin{array}{c}\text { Produc- } \\
\text { tion costs }\end{array}$ & $\begin{array}{c}\text { Operation and } \\
\text { maintenance costs in } \\
\text { the first life cycle }\end{array}$ & $\begin{array}{c}\text { Remanufactur- } \\
\text { ing costs }\end{array}$ & $\begin{array}{c}\text { Operation costs } \\
\text { in the second } \\
\text { life cycle }\end{array}$ \\
\hline 2 & 11000 & 3751.44 & 311 & 21188.25 \\
4 & 11000 & 7734.34 & 388 & 21188.25 \\
6 & 11000 & 11956.62 & 605 & 21188.25 \\
8 & 11000 & 16436.04 & 2400 & 21188.25 \\
10 & 11000 & 21188.25 & 5040 & 21188.25 \\
\hline \hline
\end{tabular}

TABLE XII

AVERAGE COST INDEX FOR EACH OF THE FIVE DIFFERENT REMANUFACTURING POINTS

\begin{tabular}{cccccc}
\hline \hline $\begin{array}{c}\text { Remanufacturing } \\
\text { time(year) } n\end{array}$ & 2 & 4 & 6 & 8 & 10 \\
\hline $\begin{array}{c}\text { the average cost } \\
\text { index } C_{i}\end{array}$ & 3020.89 & 2879.33 & 2796.87 & 2834.68 & 2920.83 \\
\hline \hline
\end{tabular}


lowing average cost index function was obtained through fitting a conic curve to the Average Cost Index Curve:

$$
C(n)=10.3 n^{2}-135.6 n+3251.8
$$

\section{Optimum active remanufacturing point}

The optimal time point for the remanufacturing of the oil cylinder depends on two aspects, i.e., the environmental indicator and the economic indicator. Therefore, the best remanufacturing time can be determined by considering the following relationship:

$$
\left\{\begin{array}{c}
\min F(n)=0.215 n^{2}-5.479 n+158.16 \\
\min C(n)=10.3 n^{2}-135.6 n+3251.8 \\
0<n \leq 10
\end{array}\right.
$$

For the above expression, an optimization process was performed in MATLAB. Considering both the environmental index and the cost index, the optimum active remanufacturing time for the oil cylinder was determined to be after 6.58 years of operation.

\section{CONCLUSIONS}

An approach is proposed for determining the optimum active remanufacturing point of a component part. In this case, an oil cylinder was used as an example. Both environmental indicators and economic indicators were considered to ensure that the optimum remanufacturing time point will achieve a low environmental impact and low costs.

The Life Cycle Assessment method was adopted for assessing the environmental impact of the oil cylinder over the whole service life, including the remanufacturing process. Eight impact indicators were considered during the evaluation, as this will provide a comprehensive evaluation with regard to the actual situation.

An average annual cost model was established for the whole life cycle, including the remanufacturing processes. Based on environmental and economic considerations, the optimum active remanufacturing point for the oil cylinder was determined for an oil cylinder as an illustrative example.

In addition to the economic and environmental factors on the remanufacturing of used part, other factors influencing the decision for active remanufacturing scheme include remanufacturing technological, energy consumption of remanufacturing processes, and reliability of the used parts. These factors, as well as the feasibility of the active remanufacturing of the used components will be comprehensively considered in further studies to realize a maximization of the remanufacturing value.

\section{ACKNOWLEDGMENT}

The work described in this paper was supported by the National Natural Science Foundation of China (51205295), the National High-Tech. R\&D Program, China (No. 2014AA041504), the National Science Foundation, China (No. 51275365), Wuhan Youth Chenguang Program of Science and Technology (2014070404010214). These financial contributions are gratefully acknowledged.

\section{REFERENCES}

[1] A. Rashid, M. A. Asif, P. Krajnik, et al."Resource conservative manufacturing: an essential change in business and technology paradigm for sustainable manufacturing," JCP, vol. 57, no.15, 166-177, 2013. https://doi.org/10.1016/j.jclepro.2013.06.012
[2] C .A. Pigosso, E. T. Zanette, A. G. Filho, et al,“ Ecodesign methods focused on remanufacturing," JCP,vol.18, no.1, pp.21-31, 2010.

[3] B.S. Xu, "Construction machinery remanufacturing and key technologies," Construction Machinery and Equipment, vol. 40, no.8, pp.1-5, 2009.

[4] X. Zhou, Q.D. Ke, S. X. Song, et al., "An evaluation method based on mechanical parts structural characteristics for proactive remanufacturing," Procedia CIRP, vol.15, pp. 223 - 227,2014 https://doi.org/10.1016/j.procir.2014.06.095

[5] S. Zhu, J. Yao, " Remanufacturing design" In Theory and application of remanufacturing design. 1th ed. Beijing: China. China Machine Express, 2009, pp. 81-83.

[6] G. F. Liu, T. LIU, Q. D. Ke, et al,"Time interval decision-making methods for active remanufacturing product based on game theory and neural network," Journal of Mechanical Engineering,vol.49, no.7, pp. 29-35, 2013. https://doi.org/10.3901/JME.2013.07.029

[7] M. Donna, D. L. Thurston, "Incorporating component reuse, remanufacture, and recycle into product portfolio design," IEEE Trans. Engineering Management, vol. 4, no.49, pp.479-489, 2002.

[8] O. Susumu, M. Toshimitsu, O. Norio, "Environmental effects of physical life span of a reusable unit following functional and physical failures in a remanufacturing system," IJPR,vol.41, no.16, pp.3667-3687, 2003. https://doi.org/10.1080/002075403100012 0104

[9] M. Chen, X. X. Liu, "Theory of product design for remanufacturing," Journal of Machine Design, vol.22, pp.25-26,2005.

[10] G.Q. Zang, X.D. Jing, G.Q. Pu, et al. "Assessment on remanufacture ability of the automobile engines," China Mechanical Engineering, , vol.16, no.8, pp.739-742, 2005.

[11] J. X. Yang, C. Xu, S. R. Wang. Methodology and application of life cycle assessment. 1th ed. Beijing,China,Meteorological press, 2002, pp.95-96.

[12] T. Liu. "Research on Time interval decision-making and control methods for active remanufacturing,"Ph.D. dissertation, Dept. Mechanics institute, Hefei University of Technology, Hefei, China, 2012.

\section{AUTHORS}

Qin Xiang, female, was born in 1983, at present doctor is reading at Wuhan University of Science \& Technology in china. Her main research interests include green manufacturing and remanufacturing. (249008367@qq.com)

Hua Zhang, female, was born in 1964, Ph.D., Now employed in Wuhan University of Science \& Technology in china as professor, doctoral tutor. Her main research fields include green manufacturing, manufacturing systems engineering, and manufacturing information. (zhanghua403@163.com)

Zhi-gang Jiang, male, was born in 1978, PhD, Now employed in Wuhan University of Science \& Technology in china as professor. His main research directions are the green manufacturing, remanufacturing, and manufacturing systems engineering. (jzg100@163.com )

Shuo Zhu, male, was born in 1989 , at present doctor is reading at Wuhan University of Science \& Technology in china. His main research interests include green manufacturing and remanufacturing. (349472959@qq.com)

Wei Yan, male, was born in 1981, Now employed in Wuhan University of Science \& Technology in china as engineer. His main research interests include green manufacturing and remanufacturing. (dreamboat027@163.com)

This work was supported in part by the National Natural Science Foundation of China (51205295), the National High-Tech. R\&D Program, China (No. 2014AA041504), the National Science Foundation, China (No. 51275365), Wuhan Youth Chenguang Program of Science and Technology (2014070404010214). Submitted 26 October 2916. Published as resubmitted by the authors 27 November 2016. 